\title{
Ameliorating Effects of Water-Soluble Polysaccharides from Woody Ear (Auricularia auricula-judae Quel.) in Genetically Diabetic KK-A ${ }^{\mathrm{y}}$ Mice
}

\author{
Zuomin Yuan, ${ }^{1, *}$ Puming $\mathrm{HE}^{2}$ and Hisanao TAKEUCHI ${ }^{2}$ \\ ${ }^{1}$ The United Graduate School of Agricultural Science, Gifu University, \\ Gifu 501-1193, Japan \\ ${ }^{2}$ Department of Applied Biological Chemistry, Faculty of Agriculture, \\ Shizuoka University, Shizuoka 422-8529, Japan
}

(Received May 12, 1998)

\begin{abstract}
Summary We investigated the ameliorating effects of the three groups of water-soluble polysaccharides, a mixture of crude polysaccharides (FA), acidic polysaccharide fractions (FA-A), and neutral polysaccharide fractions (FA-N), obtained from the hot water extracts of the fruit bodies of Auricularia auricula-judae Quel. in genetically diabetic KK- $\mathrm{A}^{\mathrm{y}}$ mice from 6 to 11 weeks of age. Male mice were divided into five dietary groups: 1) control group, given a basal diet; 2) FA group, given an FA diet (15 g FA/kg diet); 3) FA-A group, given an FA-A diet (8 g FA-A/kg diet); 4) low FA-N group, given a low FA-N diet ( $2 \mathrm{~g}$ FA-N/kg diet); and 5) high FA-N group, given a high FA-N diet ( $8 \mathrm{~g}$ FA-N $/ \mathrm{kg}$ diet). Compared with the control diet, FA supplementation had significant effects in lowering fasting and nonfasting blood glucose, $\mathrm{HbA}_{1 \mathrm{c}}$, urinary glucose, food intake, and water intake. FA administration also improved glucose tolerance to intraperitoneal glucose loading, but it did not affect the nonfasting insulin level. FA-N supplementation had dose-dependent effects in lowering fasting and nonfasting blood glucose, insulin, $\mathrm{HbA}_{1 \mathrm{c}}$, urinary glucose, food intake, and water intake. However, the glucose tolerance was not ameliorated by either the low or the high FA-N diet. FA-A administration showed no beneficial effects in $\mathrm{KK}-\mathrm{A}^{\mathrm{y}}$ mice.
\end{abstract}

Key Words Auricularia auricula-judae Quel., water-soluble polysaccharides, $\mathrm{KK}-\mathrm{A}^{\mathrm{y}}$ mice, hypoglycemic effect

The fruit bodies of Auricularia auricula-judae Quel. (A. auricula-judae), family of Heterobasidiae (woody ears in English, mu-er in Chinese, and kikurage in Japanese), is among the most popular edible mushrooms in China and Japan, and since ancient times it also has been used to cure several diseases in China (1). We

* Present address: Department of Applied Biological Chemistry, Faculty of Agriculture, Shizuoka University, Shizuoka 422-8529, Japan. 
recently reported that dietary supplementation with the fruit bodies of $A$. auriculajudae at a dose of $50 \mathrm{~g} / \mathrm{kg}$ of diet could lower fasting and postprandial blood glucose levels, increase insulin secretion, and ameliorate glucose tolerance to oral glucose loading in neonatally streptozotocin diabetic rat (2), an animal model of experimental noninsulin-dependent diabetes mellitus (NIDDM) with hypoinsulinemia and impaired glucose tolerance (3). In our previous studies, we found that dietary supplementation with the fruit bodies of $A$. auricula-judae at a dose of $50 \mathrm{~g} / \mathrm{kg}$ of diet also could improve fasting blood glucose and reduce food intake in $\mathrm{KK}-\mathrm{A}^{\mathrm{y}}$ mice (unpublished data), an animal model of genetical NIDDM with hyperglycemia, hyperinsulinemia, glucosuria, and impaired glucose tolerance to intraperitoneal glucose loading (4). Furthermore, our previous studies also indicated that dietary supplementation with $\mathrm{EtOH}$-soluble fractions, water-soluble low molecular weight fractions, and water-insoluble polysaccharide fractions from $A$. auricula-judae could not improve fasting blood glucose and reduce food intake in $\mathrm{KK}-\mathrm{A}^{\mathrm{y}}$ mice (unpublished data). In the present study, we try to learn whether water-soluble polysaccharides from $A$. auricula-judae would have beneficial effects on NIDDM.

According to the report of Sone et al, the water-soluble polysaccharides of $A$. auricula-judae contained a large amount of acidic heteropolysaccharide and a small amount of neutral $\beta$-D-glucan (5). The purpose of the present study is to examine the ameliorating effects of the three groups of water-soluble polysaccharides-a mixture of crude polysaccharides (FA), acidic polysaccharide fractions (FA-A), and neutral polysaccharide fractions (FA-N) - from the fruit bodies of A. auricula-judae in $\mathrm{KK}-\mathrm{A}^{\mathrm{y}}$ mice.

\section{MATERIALS AND METHODS}

Extraction and fractionation of the polysaccharides. The dried fruit bodies of A. auricula-judae, which were harvested in China and purchased at a market in Shizuoka City, Japan, were powdered by a mixer and passed through a $1 \mathrm{~mm}$ mesh sieve. As shown in Fig. 1, the powdered sample was extracted repeatedly with $85 \%$ ethanol at room temperature, and the resultant soluble substances were filtrated to remove components of low molecular weight. The residual material was extracted with boiling water and fractionated to give crude polysaccharide fractions (FA) in $25.5 \%$ yield. Then FA was further fractionated by treatment with cetylpyridinium chloride to give acidic polysaccharide fractions (FA-A) in $15.5 \%$ yield and neutral polysaccharide fractions (FA-N) in $2.6 \%$ yield. FA, FA-A, and FA-N were powered with a mixer and used in this study.

Animal, diet, and experimental design. Thirty-five male $\mathrm{KK}-\mathrm{A}^{\mathrm{y}} / \mathrm{Ta} \mathrm{Jcl}$ mice, weighing 18-22 g, were purchased from Clea Japan (Tokyo, Japan) at 4 weeks of age. The experimental plan was approved by the Laboratory Animal Care Committee of the Faculty of Agriculture, Shizuoka University. The mice were individually housed in hanging stainless-steel wire cages and kept in an isolated 


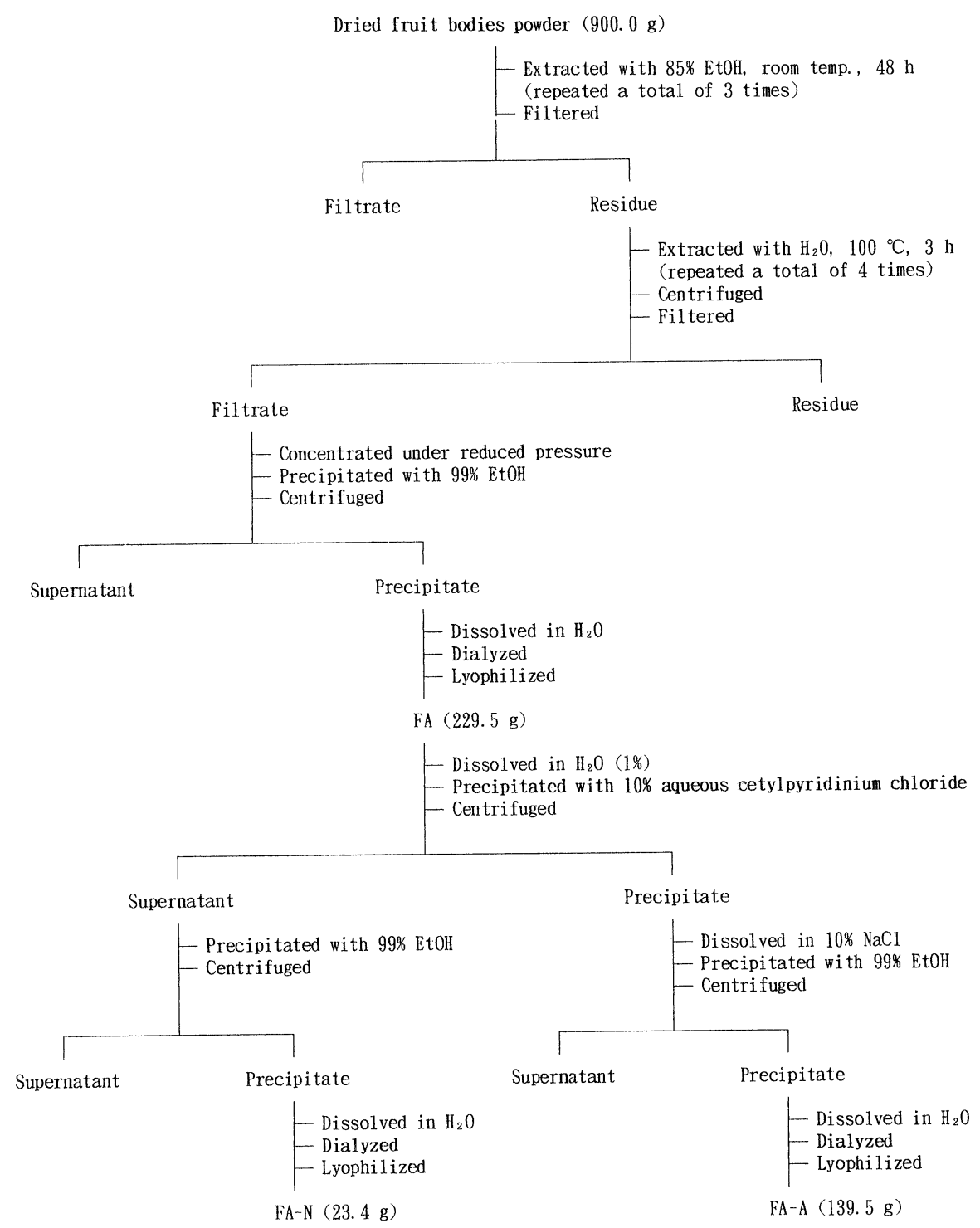

Fig. 1. Extraction and fractionation of water-soluble polysaccharides from fruit bodies of Auricularia auricula-judae Quel.

room with a controlled temperature $\left(23-25^{\circ} \mathrm{C}\right)$ and controlled humidity $(40-60 \%)$ and a $12 \mathrm{~h}$ cycle of light and dark (light on from 06:00 to 18:00). Table 1 shows the composition of experimental diets. The composition of basal diet (control diet) was based on the AIN-76 ${ }^{\mathrm{TM}}$ diet (6). The FA, FA-A, and FA-N powders were added to the basal diet at the expense of cellulose. The amounts of FA, FA-A, and 
Table 1. Composition of experimental diets.

\begin{tabular}{|c|c|c|c|c|c|}
\hline Ingredient & $\begin{array}{c}\text { Basal } \\
\text { (control) } \\
\text { died }\end{array}$ & $\begin{array}{l}\text { FA } \\
\text { diet }\end{array}$ & $\begin{array}{c}\text { FA-A } \\
\text { diet } \\
(\mathrm{g} / \mathrm{kg} \text { diet })\end{array}$ & $\begin{array}{c}\text { Low FA-N } \\
\text { diet }\end{array}$ & $\begin{array}{l}\text { High FA-N } \\
\text { died }\end{array}$ \\
\hline Casein & 200 & 200 & 200 & 200 & 200 \\
\hline DL-Methionine & 3 & 3 & 3 & 3 & 3 \\
\hline$\alpha$-Cornstarch & 450 & 450 & 450 & 450 & 450 \\
\hline Sucrose & 200 & 200 & 200 & 200 & 200 \\
\hline Corn oil & 50 & 50 & 50 & 50 & 50 \\
\hline Mineral mixture $^{1}$ & 35 & 35 & 35 & 35 & 35 \\
\hline Vitamin mixture $^{1}$ & 10 & 10 & 10 & 10 & 10 \\
\hline Choline chloride & 2 & 2 & 2 & 2 & 2 \\
\hline Cellulose & 50 & 35 & 42 & 48 & 42 \\
\hline $\mathrm{FA}^{2}$ & 0 & 15 & 0 & 0 & 0 \\
\hline $\mathrm{FA}-\mathrm{A}^{3}$ & 0 & 0 & 8 & 0 & 0 \\
\hline $\mathrm{FA}-\mathrm{N}^{4}$ & 0 & 0 & 0 & 2 & 8 \\
\hline \multicolumn{6}{|c|}{$\begin{array}{l}{ }^{1} \text { AIN- } 76{ }^{\mathrm{TM}} \text { (Nihon Nosan Kogyo, Yokohama, Japan). } \\
{ }^{2} \text { FA: the mixture of water-soluble crude polysaccharides from fruit bodies of Auricularia } \\
\text { auricula-judae. } \\
{ }^{3} \text { FA-A: water-soluble acidic polysaccharide fractions from fruit bodies of Auricularia } \\
\text { auricula-judae. } \\
{ }^{4} \text { FA-N: water-soluble neutral polysaccharide fractions from fruit bodies of Auricularia } \\
\text { auricula-judae. }\end{array}$} \\
\hline
\end{tabular}

FA-N in their respective diets were to correspond to the amounts in the fruit bodies of $A$. auricula-judae at the dose of $50 \mathrm{~g} / \mathrm{kg}$ of diet in our previous study. The amount of FA-N in the high FA-N diet was equivalent to the amount of FA-A in the FA-A diet.

The mice were fed a basal diet for 2 weeks. They were then randomly divided into 5 dietary groups of 7 mice each with similar mean body weights and $5 \mathrm{~h}$ fasting plasma glucose concentrations. The animals were allowed free access to the experimental diets and water for 5 weeks. Food consumption and water intake were recorded daily. Body weight and fasting plasma glucose were measured weekly in mice following $5 \mathrm{~h}$ of food deprivation. Blood samples were collected under nonanesthesia from the tail vein into heparinized capillary tubes (Funakoshi Pharmaceutical, Tokyo, Japan), and plasma was immediately separated by centrifugation $(9,000 \times g, 5 \mathrm{~min})$ to determine glucose concentration. Urinary glucose was investigated during the 5 th week of feeding. Urine was collected over a $24 \mathrm{~h}$ period with $5 \mathrm{~mL}$ of $1 \mathrm{~N}$ hydrochloric acid to keep the urine from decaying, and the urinary sample was diluted to $500 \mathrm{~mL}$ for a determination of glucose concentration.

The intraperitoneal glucose tolerance test (IP-GTT) was performed in each mouse under nonanesthesia 5 weeks after feeding the experimental diets. The mice 
Table 2. Body weight gain, food intake, and water intake in $\mathrm{KK}-\mathrm{A}^{\mathrm{y}}$ mice fed the experimental diets in Table 1 for 5 weeks.

\begin{tabular}{lccc}
\hline $\begin{array}{c}\text { Dietary } \\
\text { group }\end{array}$ & $\begin{array}{c}\text { Body weight } \\
\text { gain }\end{array}$ & $\begin{array}{c}\text { Food } \\
\text { intake } \\
(\mathrm{g} / 35 \mathrm{~d})\end{array}$ & $\begin{array}{c}\text { Water } \\
\text { intake }\end{array}$ \\
\hline Control & $9.5 \pm 0.2^{1}$ & $193 \pm 3^{\mathrm{a}}$ & $577 \pm 36^{\mathrm{a}}$ \\
FA & $9.1 \pm 0.3$ & $180 \pm 2^{\mathrm{b}}$ & $404 \pm 28^{\mathrm{b}}$ \\
FA-A & $9.0 \pm 0.2$ & $199 \pm 3^{\mathrm{a}}$ & $621 \pm 22^{\mathrm{a}}$ \\
Low FA-N & $8.9 \pm 0.5$ & $182 \pm 2^{\mathrm{b}}$ & $423 \pm 32^{\mathrm{b}}$ \\
High FA-N & $8.3 \pm 0.6$ & $139 \pm 4^{\mathrm{c}}$ & $206 \pm 16^{\mathrm{c}}$ \\
\hline
\end{tabular}

${ }^{1}$ Values are mean \pm SE for 7 mice. Values in a column with different superscript letters are significantly different at $p<0.05$.

received a $10 \%$ glucose solution ( $1 \mathrm{~g}$ glucose $/ \mathrm{kg}$ body weight) intraperitoneally following $18 \mathrm{~h}$ of food deprivation. Blood samples were collected from the tail vein before and 30,60, and 120 min after the loading of glucose. Plasma was immediately separated by centrifugation for measurement of glucose concentration.

On the final day of the experiment, the mice were sacrificed by decapitation under nonanesthesia and nonfasting. The blood samples were collected in polyethylene tubes with heparin for the measurement of $\mathrm{HbA}_{1 \mathrm{c}}$ levels and without heparin for the measurement of nonfasting serum glucose and insulin concentrations. Serum was harvested by centrifugation $\left(2,000 \times \mathrm{g}, 20 \mathrm{~min}, 4^{\circ} \mathrm{C}\right)$.

Analytical procedures. The concentrations of blood glucose and urinary glucose were determined by the glucose oxidase method with a kit (Glucose C-II-Test, Wako Pure Chemical Industries, Osaka, Japan). Serum insulin level was determined by an enzyme-linked immunosorbent assay (ELISA) with a kit (Glazyme Insulin-EIA-Test, Wako Pure Chemical Industries). $\mathrm{HbA}_{1 \mathrm{c}}$ was measured by cation exchange column with a kit (Hemoglobin $\mathrm{A}_{1 \mathrm{c}}$ Micro Column Test, ROPET $\mathrm{A}_{1 \mathrm{c}} \mathrm{s}$, Nippon Chemiphar, Tokyo, Japan).

Statistical analysis. Data in the experiment are showed as mean \pm SE. All data were analyzed by one-way analysis of variance, and the differences between means were established by using Duncan's multiple-range test (7). The statistical significance of differences was established at $p<0.05$.

\section{RESULTS}

Effect of polysaccharides on body weight, food intake, and water intake

The body weight gain, food intake, and water intake are presented in Table 2. The overall body weight gain tended to be reduced by supplementation of the water-soluble polysaccharides of $A$. auricula-judae, especially in mice fed the high FA-N diet, but no statistical differences were found among the 5 groups. When 


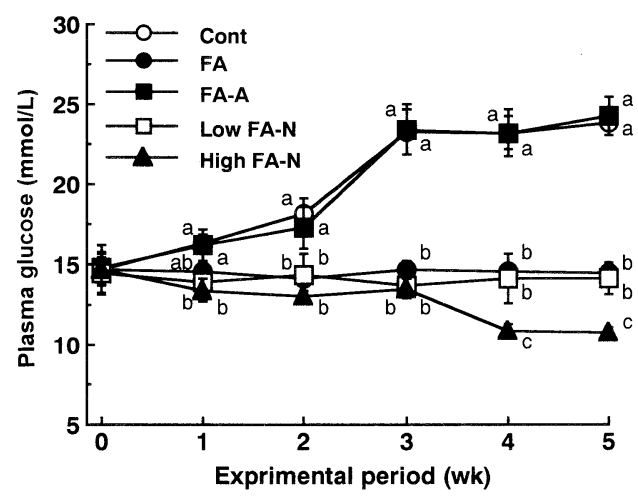

Fig. 2. Effects of water-soluble polysaccharides from fruit bodies of Auricularia auricula-judae on plasma glucose concentrations following $5 \mathrm{~h}$ of food deprivation in $\mathrm{KK}-\mathrm{A}^{y}$ mice. The mice were divided into five dietary groups and were fed the experimental diets in Table 1 for 5 weeks. The symbols and bars represent the mean and SE, respectively, for 7 mice. At each time, values with different letters are significantly different at $p<0.05$.

overall means were compared, food intake and water intake were, respectively, about $7 \%$ and $30 \%$ lower in mice fed the FA diet, $6 \%$ and $27 \%$ lower in mice fed the low FA-N diet, and $28 \%$ and $64 \%$ lower in mice fed the high FA-N diet than in mice fed the control diet. No significant differences were observed in food intake and water intake between the control group and the FA-A group.

\section{Effect of polysaccharides on fasting plasma glucose}

Figure 2 shows the changes of $5 \mathrm{~h}$ fasting plasma glucose levels. Fasting plasma glucose concentrations in the control group and the FA-A group were gradually increased with age, and no significant differences were observed between the two groups. However, this rise was markedly suppressed by the FA diet and both FA-N diets compared with the control diet. In the FA group and the low FA-N group, the concentrations of fasting plasma glucose were kept at the initial levels throughout the whole period of experiment. In the high FA-N group, fasting plasma glucose levels were almost unchanged until the $3 \mathrm{rd}$ week of the experiment, and thereafter they were significantly lower than the initial value in the 4th and 5 th weeks of the experiment $(p<0.01)$.

\section{Effect of polysaccharides on glucose tolerance}

Figure 3 shows the plasma glucose levels of the 5 dietary groups at various time intervals before and after IP-GTT. The blood glucose concentrations in the FA group were significantly lower before and 30,60, and 120 min after the loading of glucose than in the control group. The delta area under the plasma glucose response curve $(8)$ significantly decreased in the FA group $(1.8 \pm 0.2 \mathrm{mmol} / \mathrm{L} \cdot \mathrm{h})$ compared 
with that in the control group $(5.9 \pm 0.4 \mathrm{mmol} / \mathrm{L} \cdot \mathrm{h}, p<0.01)$. However, these differences were not significantly apparent in mice fed an FA-A or an FA-N diet (data not shown).

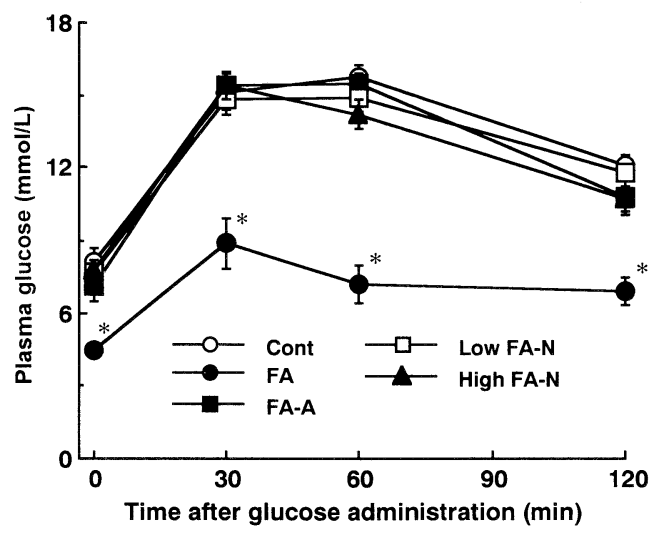

Fig. 3. Effects of water-soluble polysaccharides from fruit bodies of Auricularia auricula-judae on plasma glucose response to glucose tolerance test in $\mathrm{KK}-\mathrm{A}^{\mathrm{y}}$ mice. The mice were divided into five dietary groups. After being fed the experimental diets in Table 1 for 5 weeks, they were given $10 \%$ glucose solution $(1 \mathrm{~g} / \mathrm{kg}$ body weight) intraperitoneally following $18 \mathrm{~h}$ of food deprivation. The symbols and bars represent the mean and SE, respectively, for 7 mice. The value with an asterisk is significantly different from other values at the same time, $p<0.05$.

Table 3. Urinary glucose, serum glucose, serum insulin, and $\mathrm{HbA}_{1 \mathrm{c}}$ levels in $\mathrm{KK}-\mathrm{A}^{\mathrm{y}}$ mice. $^{1}$

\begin{tabular}{lcccc}
\hline $\begin{array}{c}\text { Dietary } \\
\text { group }\end{array}$ & $\begin{array}{c}\text { Urinary } \\
\text { glucose } \\
(\mathrm{mmol} / 24 \mathrm{~h} / 50 \mathrm{~g})\end{array}$ & $\begin{array}{c}\text { Serum } \\
\text { glucose } \\
(\mathrm{mmol} / \mathrm{L})\end{array}$ & $\begin{array}{c}\text { Serum } \\
\text { insulin } \\
(\mu \mathrm{U} / \mathrm{mL})\end{array}$ & $\begin{array}{c}\mathrm{HbA}_{1 \mathrm{c}} \\
(\%)\end{array}$ \\
\hline Control & $9.4 \pm 0.6^{\mathrm{a}, 2}$ & $46.0 \pm 1.3^{\mathrm{a}}$ & $628 \pm 59^{\mathrm{a}}$ & $3.4 \pm 0.1^{\mathrm{a}}$ \\
FA & $4.0 \pm 0.2^{\mathrm{c}}$ & $36.2 \pm 2.4^{\mathrm{b}}$ & $660 \pm 57^{\mathrm{a}}$ & $2.5 \pm 0.3^{\mathrm{bc}}$ \\
FA-A & $9.7 \pm 0.4^{\mathrm{a}}$ & $45.8 \pm 1.4^{\mathrm{a}}$ & $625 \pm 58^{\mathrm{a}}$ & $3.2 \pm 0.3^{\mathrm{ab}}$ \\
Low FA-N & $6.8 \pm 0.6^{\mathrm{b}}$ & $41.8 \pm 1.3^{\mathrm{a}}$ & $584 \pm 49^{\mathrm{a}}$ & $2.8 \pm 0.2^{\mathrm{bc}}$ \\
High FA-N & $0.0 \pm 0.0^{\mathrm{d}}$ & $13.9 \pm 0.4^{\mathrm{c}}$ & $365 \pm 28^{\mathrm{b}}$ & $1.9 \pm 0.3^{\mathrm{c}}$ \\
\hline
\end{tabular}

${ }^{1}$ The mice were divided into five dietary groups and fed the experimental diets in Table 1. Urine was collected over a $24 \mathrm{~h}$ period during the 5 th week of feeding. After being fed the experimental diets for 5 weeks, the mice were sacrificed by decapitation under nonfasting. The blood samples were collected for the measurement of serum glucose, serum insulin, and $\mathrm{HbA}_{1 \mathrm{c}}$.

${ }^{2}$ Values are mean \pm SE for 7 mice. Values in a column with different superscript letters are significantly different at $p<0.05$. 
Effect of polysaccharides on urinary glucose, nonfasting serum glucose, nonfasting serum insulin, and $H b A_{1 \mathrm{c}}$

The concentrations of urinary glucose, nonfasting serum glucose, nonfasting serum insulin, and $\mathrm{HbA}_{1 \mathrm{c}}$ of 5 dietary groups are presented in Table 3. No significant differences were observed in these characteristics between the control and the FA-A groups.

Urinary glucose excretions were 58\% lower in mice fed the FA diet and $28 \%$ lower in mice fed the low FA-N diet than in mice fed the control diet. Urinary glucose excretion was not detected in mice fed the high FA-N diet.

Nonfasting serum glucose and insulin concentrations were dramatically lower in mice fed the high FA-N diet than in mice fed the control diet, but these differences were not significantly apparent in mice fed the low FA-N diet. Nonfasting serum glucose levels were significantly lowered in mice fed the FA diet, but nonfasting serum insulin concentration was not changed compared with mice fed the control diet.

$\mathrm{HbA}_{1 \mathrm{c}}$ levels were significantly lowered by the FA diet and by both FA-N diets dose dependently compared with the control diet.

\section{DISCUSSION}

In this study, we examined the ameliorating effects of water-soluble polysaccharides FA, FA-A, and FA-N obtained from the hot-water extracts of the fruit bodies of $A$. auricula-judae, in genetically diabetic $\mathrm{KK}-\mathrm{A}^{\mathrm{y}}$ mice. This study showed that FA, FA-A, and FA-N had significantly different effects on glycemic control and food intake in $\mathrm{KK}-\mathrm{A}^{\mathrm{y}}$ mice.

FA is a crude polysaccharide fraction from fruit bodies of A. auricula-judae and is considered to be a mixture consisting mainly of acidic and neutral polysaccharides. The results of this study demonstrate that dietary supplementation with FA at a dose of $15 \mathrm{~g} / \mathrm{kg}$ of diet could suppress the elevation of fasting and nonfasting blood glucose levels, reduce $\mathrm{HbA}_{1 \mathrm{c}}$ and urinary glucose concentrations, and improve glucose tolerance to IP-GTT in KK-A ${ }^{y}$ mice compared with the control diet. The results of this study also indicate that FA supplementation at a dose of $15 \mathrm{~g} / \mathrm{kg}$ of diet caused a slight but significant reduction in food consumption, accompanied with a decreased water intake. These results suggest that water-soluble crude polysaccharides had significant effects on glycemic control and food intake in $\mathrm{KK}-\mathrm{A}^{\mathrm{y}}$ mice.

FA-N is a water-soluble neutral polysaccharide fraction from fruit bodies of A. auricula-judae. The results of this study showed that FA-N administration had dose-dependent effects in lowering fasting and nonfasting blood glucose, insulin, $\mathrm{HbA}_{1 \mathrm{c}}$, urinary glucose, food intake, and water intake compared with the control diet, suggesting that water-soluble neutral polysaccharide may be a major active agent of $A$. auricula-judae for improving hyperglycemia, hyperinsulinemia, glucosuria, and hyperphagia of $\mathrm{KK}-\mathrm{A}^{\mathrm{y}}$ mice. It may be worthwhile noting that 
FA-N intake, either a low or a high dose, did not ameliorate impaired glucose tolerance to IP-GTT in KK-A ${ }^{y}$ mice like FA did. At present, we have no definitive experimental evidence to explain this result. Hikino and Mizuno found that hypoglycemic activity was decreased during the purification of some polysaccharides from Ganoderma lucidum, a medicinal mushroom (9). Ukai also reported that an antiphlogistic effect of the crude polysaccharide from $A$. auricula-judae disappeared during the further fractionation of polysaccharides (10). Thus one possibility is that the ameliorating effect of $A$. auricula-judae on glucose tolerance to IP-GTT in KK-A mice was not contributed by water-soluble neutral polysaccharide alone.

Kiho et al (11) found that the water-soluble acidic polysaccharide from the fruit bodies of Tremella fuciformis (Yin-er in Chinese, shirokikurage in Japanese), along with $A$. auricula-judae belonging to the family Heterobasidiae, exhibited a significantly hypoglycemic action by a dose of $750 \mathrm{mg} / \mathrm{kg} / \mathrm{d}$ in streptozotocin-induced diabetic mice, an animal model of insulin-dependent diabetes mellitus (IDDM) (12). The constitution of the water-soluble acidic polysaccharide from Tremella fuciformis has been reported to resemble that of the water-soluble acidic polysaccharide from A. auricula-judae (13). However, in contrast to the case of Tremella fuciformis, our present study showed that the administration of the acidic polysaccharide fractions from A. auricula-judae at a dose of $1,232 \mathrm{mg} / \mathrm{kg} / \mathrm{d}$ showed no beneficial effects in $\mathrm{KK}-\mathrm{A}^{\mathrm{y}}$ mice, though FA-A was a major constituent of the water-soluble polysaccharides of $A$. auricula-judae and the dose of FA-A in the FA diet was the same as that of FA-N in the high FA-N diet.

The hypoglycemic action of dietary fiber to diabetes was often considered to be due to an increased consumption of dietary fiber in large quantities $(14,15)$. The American Diabetes Association has revised its position on medical nutrition therapy for people with diabetes mellitus. The 1994 recommendation for dietary fiber is the same for persons with or without diabetes. Daily consumption of a diet containing 20-35 g dietary fiber from a wide variety of food sources is recommended (14). Several previous studies using dietary fiber levels of $45-50 \mathrm{~g} / \mathrm{d}$ showed little or no significant benefits to carbohydrate metabolism in patients with diabetes (16-18), and the greatest effects on carbohydrate metabolism have relied on dietary fiber levels from 70 to $100 \mathrm{~g} / \mathrm{d}(19-21)$, but these levels of dietary fiber intake may be impossible to achieve consistently in a large segment of the population (15). On the other hand, most of the previous studies on dietary fiber in diabetic patients or diabetic animals used single-type dietary fiber such as water-soluble dietary fiber or water-insoluble dietary fiber as a food admixture. In our present study, the total amount of dietary fiber in FA and both FA-N diets was kept at the same level as that in the basal diet. When cellulose of the basal diet, a water-insoluble polysaccharide that has been indicated to have no hypoglycemic effect in $\mathrm{KK}-\mathrm{A}^{\mathrm{y}}$ mice (22), was partially exchanged by water-soluble polysaccharides FA or FA-N, significant beneficial effects were observed in $\mathrm{KK}-\mathrm{A}^{\mathrm{y}}$ mice. The effective dose in low FA-N diet is about $300 \mathrm{mg} / \mathrm{kg} / \mathrm{d}$. The results of the present study suggest that the hypoglycemic effect of dietary fiber might be related to its type rather than to the 
amount consumed. Increasing the rate of some water-soluble dietary fibers, which have been confirmed to be effective in improving diabetic symptoms, in total dietary fiber intake might be more beneficial to diabetic patients for their dietary management than for only increasing dietary fiber consumption in large quantities.

Several studies reported that the reduction of food intake usually produced lower body weight in mouse and rat (23-25). In our present study, however, the reduction of food intake by the supplementation of FA or FA-N did not significantly affect the body weight gain of $\mathrm{KK}-\mathrm{A}^{\mathrm{y}}$ mice. This result may be due to the improvement of glucose utilization and/or metabolization in diabetic mice fed the FA or FA-N diet. On the other hand, it is likely that decreased calorie intake contributed to the ameliorating effects of water-soluble polysaccharides of $A$. auricula-judae on glycemic control in $\mathrm{KK}-\mathrm{A}^{\mathrm{y}}$ mice. Further experiments using a dietary restriction are needed to clarify this hypothesis.

$\mathrm{KK}-\mathrm{A}^{y}$ mice had genetically determined hyperinsulinemia. In this study, FA-N was considered to be a major active agent of $A$. auricula-judae for improving hyperinsulinemia and showed a significantly dose-dependent trend. When mice were fed the high FA-N diet in which the dose of FA-N was about 4 times greater than in the fruit bodies of $A$. auricula-judae at a dose of $50 \mathrm{~g} / \mathrm{kg}$ of diet, the nonfasting insulin level was dramatically lowered. In this study, FA administration improved nonfasting serum glucose concentration, but it did not affect the nonfasting serum insulin level. One reason for this insufficiency might be due to the FA dose used in this study, which was enough to improve hyperglycemia, but not enough to improve hyperinsulinemia of $\mathrm{KK}-\mathrm{A}^{\mathrm{y}}$ mice because the FA-N dose in the FA diet was insufficient. The administration of a low FA-N diet showed a similar result in the nonfasting serum insulin level, as the FA diet did.

At present, the mechanism of the ameliorating effects of water-soluble crude polysaccharide fractions and neutral polysaccharide fractions from $A$. auricula-judae in $\mathrm{KK}-\mathrm{A}^{\mathrm{y}}$ mice are unknown. Further studies are in progress.

In conclusion, this study demonstrates the ameliorating effects of the watersoluble polysaccharides from $A$. auricula-judae in $\mathrm{KK}-\mathrm{A}^{\mathrm{y}}$ mice, and it confirms that these beneficial effects on glycemic control and food intake are mainly contributed by the water-soluble neutral polysaccharides, but not by the watersoluble acidic polysaccharides. Water-soluble polysaccharides of $A$. auriculajudae, especially the water-soluble neutral polysaccharides, may be the good dietary fiber source in the dietary management of NIDDM and may have beneficial effects on improving diabetic symptoms.

\section{REFERENCES}

1) Nanba T. 1992. Medicinal mushrooms in Chinese medicines. In: Chemistry and Biochemistry of Mushrooms (Mizuno T, Kawai M, eds), p 251-267. Institute Press Centre, Tokyo.

2) Yuan Z, He P, Takeuchi H. 1998. Ameliorating effects of Auricularia auricula-judae 
Quel. on blood glucose level and insulin secretion in streptozotocin-induced diabetic rats. J Jpn Soc Nutr Food Sci 51: 129-133.

3) Portha B, Blondel O, Serradas P, McEvoy R, Giroix MH, Kergoat M, Bailbe D. 1989. The rat models of non-insulin dependent diabetes induced by neonatal streptozotocin. Diabetes Metab 15: 61-75.

4) Iwatsuka H, Shino A, Suzuoki Z. 1970. General survey of diabetic features of yellow KK mice. Endocrinol Jpn 17: 23-35.

5) Sone Y, Kakuta M, Misaki A. 1978. Isolation and characterization of polysaccharides of "Kikurage," fruit body of Auricularia auricula-judae. Agric Biol Chem 42: 417-425.

6) The American Institute of Nutrition. 1977. Report of the American Institute of Nutrition Ad Hoc Committee on standards for nutritional studies. $J$ Nutr 107: 1340-1348.

7) Duncan DM. 1957. Multiple range tests for correlated and heteroscedastic means. Biometrics 13: 164-176.

8) Odaka H, Shino A, Ikeda H, Matsuo T. 1992. Antiobesity and antidiabetic actions of a new potent disaccharidase inhibitor in genetically obese-diabetic mice, KK-A ${ }^{\mathrm{Y}} . J$ Nutr Sci Vitaminol 38: 27-37.

9) Hikino H, Mizuno T. 1989. Hypoglycemic actions of some heteroglycans of Ganoderma lucidum fruit bodies. Planta Med 55: 385.

10) Ukai S. 1992. Active agent in antiphlogosis. In: Chemistry and Biochemistry of Mushrooms (Mizuno T, Kawai M, eds), p 87-91. Institute Press Centre, Tokyo.

11) Kiho T, Tsujimura Y, Sakushima M, Usui S, Ukai S. 1994. Polysaccharides in fungi. XXXIII. Hypoglycemic activity of an acidic polysaccharide (AC) from Tremella fuciformis. Yakugaku Zasshi 114: 308-315.

12) Rakieten N, Rakieten ML, Nadkarni MV. 1963. Studies on the diabetogenic action of streptozotocin. Cancer Chemother Rep 29: 91-98.

13) Kakuta M, Sone Y, Umeda T, Misaki A. 1979. Comparative structural studies on acidic heteropolysaccharides isolated from "Shirokikurage," fruit body of Tremella fuciformis Berk, and the growing culture of its yeast-like cells. Agric Biol Chem 43: 1659-1668.

14) New recommendations and principles for diabetes management. 1994. Nutr Rev 52: $238-241$.

15) Hollenbeck CB, Coulston AM. 1990. Diabetes mellitus. In: Present Knowledge in Nutrition (Brown ML, ed), p 362-370. International Life Sciences Institute-Nutrition Foundation, Washington, DC.

16) Hollenbeck CB, Coulston AM, Reaven GM. 1986. To what extent does increased dietary fiber improve glucose and lipid metabolism in patients with noninsulindependent diabetes mellitus (NIDDM)? Am J Clin Nutr 43: 16-24.

17) Riccardi G, Rivellese A, Pacioni D. 1984. Separate influences of dietary carbohydrate and fiber on metabolic control of diabetes. Diabetologia 26: 116-121.

18) Uusitupa M, Siitonen O, Savolainen K, Silvasti M, Penttila I. 1989. Metabolic and nutritional effects of long-term use of guar gum in the treatment of noninsulin-dependent diabetes of poor metabolic control. Am J Clin Nutr 49: 345-351.

19) Simpson HCR, Simpson RW, Lousley S, Mann J. 1981. High carbohydrate leguminous fibre diet improves all aspects of dietary control. Lancet 1: 1-5.

20) Jenkins DJA, Leeds AR, Gassull MA, Cochet B, Alberti KGMM. 1977. Decrease in postprandial insulin and glucose concentrations by guar and pectin. Ann Intern Med 86: $20-23$.

21) Simpson RW, Mann JI, Eaton J. 1979. Improved glucose control in maturity-onset diabetes treated with high-carbohydrate-modified fat diets. $B r J$ Med 1: 1753-1756. 
22) Kakuda T, Sakane I, Takihara T, Ozaki Y, Takeuchi H, Kuroyanagi M. 1996. Hypoglycemic effect of extracts from Lagerstroemia speciosa L. leaves in genetically diabetic KK-A ${ }^{\mathrm{Y}}$ mice. Biosci Biotech Biochem 60: 204-208.

23) Overton JM, VanNess JM, Casto RM. 1997. Food restriction reduces sympathetic support of blood pressure in spontaneously hypertensive rats. $J$ Nutr 127: 655-660.

24) Boissonneault GA, Harrison DE. 1994. Obesity minimizes the immunopotentiation of food restriction in $\mathrm{Ob} / \mathrm{Ob}$ mice. $J$ Nutr 124: 1639-1646.

25) Cleary MP, Muller S, Lanza-Jacoby S. 1987. Effects of long-term moderate food restriction on growth, serum factors, lipogenic enzymes and adipocyte glucose metabolism in lean and obese zucker rats. J Nutr 117: 355-360. 